\title{
The 1918 flu pandemic and its aftermath
}

\author{
Norman A. Johnson*
}

\author{
Book details \\ A review of L. Spinney. 2017 \\ Pale Rider: The Spanish Flu of 1918 and How It Changed the World \\ Public Affairs \\ 352 pg., ISBN: 978-1610397674.
}

Keywords: 1918 influenza, Disease evolution, Evolutionary medicine, History, History of medicine

As I write at the start of February 2018, the United States is going through a nasty influenza season. Hospital visits for the flu are far above the baseline of the last decade. Already over 50 number of children have died from the epidemic. Confounding efforts to contain the disease is the reduced effectiveness of this season's vaccine (Sun 2018). But this most recent season pales in comparison with the 1918-1919 influenza pandemic which killed more people than those who died in battle in the First World War and perhaps as many as 100 million people.

Laura Spinney, a British science journalist and a novelist, presents a fascinating and wide-ranging account of this pandemic. Although several books have been written about the pandemic (e.g., Berry 2005), these left considerable voids. Recent research in realms spanning from historiography to epidemiology to phylogenetics have helped fill in these gaps. As we arrive at the centennial of this pandemic, Spinney's book provides synthesis and context to these new findings.

The pandemic came in three waves in quick succession: spring 1918, fall 1918, and 1919. Some, but not most, accounts list a fourth wave occurring late in 1919 and extending into 1920. The most severe flu occurred during the second wave, leading to the hypothesis that the influenza virus evolved to become more virulent in the intervening time was the most severe. Earlier

\footnotetext{
*Correspondence: njohnson@ent.umass.edu

Department of Biology, Graduate Program in Organismic

and Evolutionary Biology, University of Massachusetts Amherst, Amherst, MA 01002, USA
}

studies could not directly test this hypothesis because the sequence data they had for the virus came only from the second wave (Taubenberger and Morens 2006). Spinney discusses how recent studies that had obtained variants from the first wave victims illustrate that the virus had evolved to become better adapted to humans, though less well adapted to birds.

This pandemic has had many names. Spinney named her book Pale Rider after a Katherine Ann Porter novella, "Pale Horse, Pale Rider", about the relationship between a solider and a journalist during the pandemic. This story was influenced by Porter's personal near-death experience with this flu that had inflamed her optic nerve. As a result, Porter's color vision was diminished, leaving her seeing the world in washed-out colors. Yet despite the title, Spinney follows tradition and frequently refers to the pandemic as the "Spanish flu". I am not sure that this was the wisest of choices given how the common name arose. It came about not based on any evidence that the pandemic originated or was more severe in Spain. Instead, it arose from media perception. Most of the other major powers, including the United States, were engaged in the war. These countries minimized or censored news about the flu in their country. The neutrality of Spain allowed its newspapers to fully cover the flu, unencumbered by wartime censorship. The Spanish of the time often called the flu "The Naples soldier" (Soldado de Napoles), not because they thought it was from soldiers from Naples but because the catchiness of the flu had been compared to a song of that name from the musical operetta "The Song of the Forgetting" (La cancion del olivido). 
Biologists today name influenza strains for the categories of variants that they have at the haemagglutinin $(\mathrm{H})$ and neuramindidase $(\mathrm{N})$ genes. Fittingly, the 1918 pandemic strain has been designated as H1N1. This subtype has continued to circulate and evolve; it was the one responsible for the 2009 "swine flu" pandemic, which was widespread, but relatively mild. The main subtype of the 2017/2018 flu is H3N2.

But where did the pandemic actually begin? Spinney discusses the competing hypotheses. Some evidence points to it originating in China. An intense flu-like disease did hit the northern Chinese province Shansi in 1917, but whether that was the same flu as the subsequent worldwide epidemic is not clear. Another possibility is that the pandemic evolved from the "purulent bronchitis" that had been observed in military bases in Northern France and England in early 1917. However, no such disease was observed in the civilian population at this time. The final hypothesis, one that Berry (2005) had proposed in his earlier book on the pandemic, is that it originated in the American heartland. Farmers in Kansas had contracted a respiratory disease just a few months before reports of the first wave of the pandemic hit U. S. military bases. Spinney does not come down conclusively on the side of any of these hypotheses, but argues that the American heartland scenario is most likely.

The support for the American heartland origin comes from recent work by Worobey et al. (2014). Their work showed that all but one of the genes in the human 1918 influenza virus showed similarity to variants present in viruses collected from birds that lived in North America. This study also provides evidence that $\mathrm{H} 1$ had been circulating in human viruses well before 1918, but then recombined with an N1 variant present in birds sometime between 1914 and 1917.

As Spinney illustrates, early twentieth century medicine was a fascinating historical period in part because it rested at the border between the premodern and the modern eras. Hence, it was replete of half steps and contradictions. Germ theory was accepted by most, though far from all medical practitioners; yet, the general public was still skeptical and many clung to older ideas of contagion. Bacteria were known and observable entities in 1918. Although viruses had been postulated at the time, they were still abstract, hypothesized entities. Indeed, experimentation done during the pandemic would help establish that the influenza was due to a virus. However, viruses would remain unseen until the 1930s invention of the electron microscope. Indeed, many at the time thought the influenza was bacterial because they were observing bacteria in patients that likely came through secondary infections.
The flu didn't just inspire development of science; ironically, it also led to the propagation of pseudoscience and conspiracy theories. One of the most interesting categories of conspiracy theories was the belief that the flu was deliberately manufactured as a biological weapon. There was even fear among the British and the Americans about the flu being linked to Bayer aspirin, which was manufactured in Germany. Of course, these fears were completely ungrounded. Given the prevalence of conspiracy theories and the discouragingly large proportion of the population who are either against or hesitant about vaccinations today, we should not laugh too quickly.

Spinney also presents how the flu influenced historical events and processes. Although it caused a great deal of battlefield illness and likely sped the end of the Great War, the flu seems to have affected all sides relatively equally; hence, it probably did not affect the outcome. The flu did affect the aftermath. Many of the participants at the peace deliberations in Paris contracted the flu. It hit President Woodrow Wilson especially hard, accelerating the physical decline he had been experiencing from transient ischemic attacks ("mini strokes") and likely contributing to the massive, paralyzing stroke he sustained in October 1919. Wilson's compromised health likely led to the imposition of more draconian terms for Germany and its allies. Moreover, a weakened Wilson was unable to convince the United States to join The League of Nations. These events helped lead to the climate that spurred World War Two a generation later. Without the pandemic, the outcome might have been very different. Spinney's remarks about how the flu affected other historical figures and their ancestors provide ample grist for counterfactual histories.

The flu also had long lasting biological effects. For many who contracted it, the flu became a chronic illness. The effects even extended even to the next generation. World War Two military records showed that recruits born in 1919 who were in utero when their mothers had the flu were ever-so-slightly shorter on average than recruits who did not receive prenatal exposure to the flu.

Much is still unknown about the 1918 flu pandemic. Reasonable estimates for how many people died still vary at least fivefold (20-100 million). We still do not clearly know why the flu hit those their in 20s and early 30s especially hard. Was it because this cohort had not had prior exposure to H1N1 as some authors, notably Worobey et al. (2014), suggested? Alternatively, was it that the strong immune systems of these young adults produced violent responses (cytokine storms)?

Using infectious disease cases can be an effective and engaging way to teach the principles of evolutionary biology (Hillis 2007; Pai 2009). Providing sociocultural 
context of the history of biomedical science further engages students and can permit them to have a deeper appreciation of biology and how it relates to their personal lives (Chamany et al. 2008). Spinney's Pale Rider certainly could be used as supplemental reading in courses on the biology of disease or the history of biology and medicine, in addition to appealing to professional biologists.

\section{Authors' contributions}

The author read and approved the final manuscript.

\section{Competing interests}

The author declares that he has no competing interests.

Ethics approval and consent to participate

Not applicable.

\section{Publisher's Note}

Springer Nature remains neutral with regard to jurisdictional claims in published maps and institutional affiliations.

Received: 21 February 2018 Accepted: 24 April 2018

Published online: 30 April 2018

\section{References}

Berry JM. The great influenza: the epic story of the deadliest plague in history. Extended Paperback Edition ed. New York: Penguin Books; 2005.

Chamany K, Allen D, Tanner K. Making biology learning relevant to students: integrating people, history, and context into college biology teaching. CBE Life Sci Educ. 2008;7:267-78.

Hillis DM. Making evolution relevant and exciting to biology students. Evolution. 2007;61:1261-4.

Pai A. Evolution in action: a case study based advanced biology class at Spelman College. J Eff Teach. 2009;9:54-68.

Sun LH. Here's what you should know about the flu season this year. The Washington Post. 2018. https://www.washingtonpost.com/news/toyour-health/wp/2018/01/25/heres-what-you-should-know-about-theflu-season-this-year/. Accessed 10 Feb 2018.

Taubenberger JK, Morens DM. 1918 influenza: the mother of all pandemics. Emerg Infect Dis. 2006;12:15-22.

Worobey M, Han G-Z, Rambaut A. Genesis and pathogenesis of the 1918 pandemic H1N1 influenza virus. Proc Natl Acad Sci. 2014;111:8107-12.

\section{Submit your manuscript to a SpringerOpen ${ }^{\circ}$ journal and benefit from:}

- Convenient online submission

- Rigorous peer review

- Open access: articles freely available online

- High visibility within the field

- Retaining the copyright to your article 